\title{
PEMBERDAYAAN EKONOMI MASYARAKAT DAN PENDAYAGUNAAN APARATUR PEMERINTAH DESA PENGALANGAN KECAMATAN MENGANTI GRESIK
}

\author{
Supriyanto ${ }^{1}$ \\ ${ }^{1}$ Universitas Wijaya Putra \\ supriyanto@uwp.ac.id
}

\begin{abstract}
Abstrak
Dalam rangka menggurangi angka kemiskinan desa perlu adanya program pemberdayaan ekonomi masyarakat yang berbasis pada kelompok dan komunitas. Program tersebut akan mudah terwujud, jika di dukung oleh Sumber daya aparatur pemerintah desa yang handal. Guna meningkatkan kemampuan dan kapasitas aparat desa diperlukan program pelatihan dan pendampingan peningkatan ketrampilan dan keahlian bagi aparatur desa. Upaya untuk meningkatkan sektor ekonomi desa dengan membentuk Kelompok Tani dan GAPOKTAN dengan memberikan ketrampilan pengelolahan pupuk organik yang berbahan dasar sampah organik untuk mendorong terciptanya produk unggulan desa berbasis pada produk pertanian. Sektor pemerintah desa upaya yang dilakukan dengan memberikan pelatihan pemanfaatan Teknologi Informasi Komunikasi TIK, pengelolaan ketata usahaan dengan berbasis TIK dan penyusunan kebijakan desa dan program pembangunan yang berbasis pada analisis perumusan kebijakan yang rasional. Hasil kegiatan: a) Sektor pertanian terbentuknya kelompok tani \& GAPOKTAN, produk unggulan desa : sayur organik, bawang merah dan susu sapi guna penyuplai sayur organik di Pasar moden Ciputra dan dirintis sentra pasar desa sebagai sentra ekonomi; b) sektor pemerintah desa hasilnya terwujudnya pemerintah desa yang efektif yang didukung ketatausahaan yang tertib, rapi berbasis TIK; dihasilkan kebijakan dan program pembangunan desa yang dirancang secara rasional dan komprehensif; serta meningkatkan partisipasi masyarakat dalam pemerintah dan pembangunan;
\end{abstract}

Kata Kunci : Pemberdayaan masyarakat, Pendayagunaan Aparatur desa dan Pembangunan Desa

\section{PENDAHULUAN}

\subsection{Latar Belakang}

Desa merupakan unsur kewilayahan terkecil dari Negara Kesatuan Republik Indonesia, yang memiliki nilai strategis dalam pembangunan dan pencapaian tujuan bangsa dan negara. Pemerintah Desa sebagai unit terkecil dalam pemerintahan negara, berperan sangat penting dalam menggerakan roda pembangunan, karena Pemerintah Desa yang melaksanakan fungsi-fungsi pemerintahan pada tingkat terkecil yang berhadapan secara langsung dengan masyarakat. Perkuatan pembangunan desa, baik pada sektor pemerintahan maupun perekonomian masyarakat, perlu dilakukan secara serasi. Pemerintah Desa yang kuat akan menjadikan kinerja pemerintahan dan pembangunan desa berjalan efektif, berdaya guna dan berhasil guna. Untuk itu perlu memperkuat kapasitas dan kapabilitas aparatur pemerintah desa. Pada sisi lain, pembagunan ekonomi masyarakat desa sangat diperlukan untuk semakin meningkatkan kesejahteraan masyarakat. Adanya pemerintah desa

Ekonomi, Sosial, dan Budaya

1277 
yang kuat dengan didukung kemampuan sumberdaya aparatur yang cakap, akan dapat menggerakan pembangunan dan perekonomian desa. Tingginnya perekonomian dan kesejahteraan masyarakat nantinya akan dapat menggerakan partisipasi masyarakat dalam pembangunan dan pemerintahan menjadi lebih tinggi baik.

Kabupaten Gresik merupakan salah satu daerah penyangga ibu kota Provinsi Jawa Timur, memiliki posisi strategis dalam memperkuat perekonomian di Jawa Timur. Karena itu berbagai potensi ekonomi desa di Kabupaten Gresik harus dioptimalkan, dengan semakin meningkatkan produk-produk unggulan dengan nilai ekonomi yang tinggi. Untuk itu diperlukan pula pemerintahan desa di Kabupaten Gresik yang mampu menyusun program pembangunan dan melaksanakan program pembangunan dengan menggerakan partisipasi masyarakat.

Salah satu tantangan dalam pembangunan desa di Kabupaten Gresik adalah masih tingginya angka kemiskinan. Pada akhir tahun 2013 kemiskinan di Kabupaten Gresik sebanyak 170,90. ribu jiwa, $13,89 \%$ dari jumlah penduduk keseluruhan. Terjadinya kemiskinan, merupakan dampak dari kepincangan dalam distribusi sumberdaya dalam masyrakat. Deaton (2003) menyebutkan bahwa terjadinya kemiskinan bergantung pada apa yang terjadi pada distribusi pendapatan dan konsumsi dalam masyarakat. Secara ekonomi, masalah kemiskinan berkaitan dengan kekurangan pendapatan untuk memenuhi kehidupan layak tersebut (Esmara, 1986). Karena itu upaya pengentasan kemiskinan haruslah dengan memberdayakan yang bersangkutan agar dapat meningkatkan pendapatannya.

Salah satu pendekatan dalam pengentasan kemiskinan adalah dengan berbasis gender, yakni dengan semakin memberdayakan kaum perempuan untuk ikut serta meningkatkan kesejahteraan keluarganya. Pada perspektif ini, Suyono (2008) menekankan bahwa dalam upaya pengentasan kemiskian dengan lebih memberdayakan kaum perempuan agar ikut serta dan diperhitungkan dalam lapangan pekerjaan yang mampu menghasilkan keuntungan. Pemberdayaan kaum perempuan keluarga miskin yang dimaksudkan adalah memberikan pendidikan dan pelatihan, yang memungkinkan kaum perempuan bisa berpikir lebih rasional dan mampu menghasilkan ide-ide cemerlang yang bisa diterapkan sebagai kegiatan nyata di lapangan. Kegiatan nyata itu harus "laku jual" sehingga dapat menghasilkan nilai tambah untuk kehidupan yang lebih sejahtera (Suyono, 2008).

Bertolak dari pemikiran tersebut, sangatlah memungkinkan untuk melakukan upaya pemberdayaan perempuan keluarga miskin secara kolektif melalui jejaring masyarakat desa. Pemberdayaan keluarga miskin perlu dilakukan dengan pendekatan kelompok, karena keberdayaan keluarga miskin dipengaruhi oleh karakter kelompok dan intervensi pemberdayaan (Sjafari, 2010), dimana yang bersangkutan berada.

Pada sisi lain untuk menggerakan pemberdayaan masyarakat miskin di desa, sangat bergantung pada kemampuan aparatur pemerintah desa. Pelaksanaan program pemberdayaan juga sangat bergantung pada seberapa kuat dan seberapa efektif pemerintah desa, yang didukung perangkat teknologi yang cukup dan tepat. Karena itulah Direktorat Jenderal Pemberdayaan Masyarakat dan Desa, terus mengupayakan pemberdayaan dan pendayagunaan pemerintah desa. Hal itu sejalan dengan agenda reformasi birokrasi tahun 2010-2025 (MENPAN dan Reformasi Birokrasi, 2010) beberapa tujuan yang akan dicapai antaranya :

1) Mengurangi dan akhirnya menghilangkan setiap penyalahgunaan kewenangan publik oleh pejabat di instansi yang bersangkutan;

2) Menjadikan negara yang memiliki mostimproved bureaucracy;

3) Meningkatkan mutu pelayanan kepada masyarakat;

4) Meningkatkan mutu perumusan dan pelaksanaan kebijakan/program instansi;

5) Meningkatkan efisiensi (biaya dan waktu) dalam pelaksanaan semua segi tugas organisasi;

6) Menjadikan birokrasi Indonesia antisipatif, proaktif, dan efektif dalam menghadapi globalisasi dan dinamika perubahan lingkungan strategis.

$$
\text { Ekonomi, Sosial, dan Budaya }
$$


Berdasarkan agenda tersebut dalam meningkatkan mutu penyelenggaraan pemerintahan desa dijalankan oleh aparatur desa sebagai ujung tombaknya. Guna mewujudkan program tersebut aparatur desa diharapkan mampu dan terus berusaha untuk meningkatkan kemampuan individu, kinerja organisasi dan pelayanan yang berbasis sistem informasi. Melihat semakin besar harapan dan tuntutan masyarakat akan pelayanan di tingkat desa maka diperlukan pelatihan dan pendampingan peningkatan ketrampilan dan keahlian bagi aparatur desa. Semakin meningkatan ketrampilan dan keahlian bagi aparatur desa diharapkan akan mampu membawa perubahan untuk semakin meningkatnya kualitas dan efektivitas pemerintahan desa.

Adapun permasalahan yang ada di Desa Pengalangan Kecamatan Kabupaten Gresik upaya untuk menjadikan desa lebih mandiri, yang akan diselesaikan melalui program ini adalah : Sektor Perekonomian Desa : belum adanya produk unggulan desa; belum adanya pemberdayaan kepada kelompok tani; belum adanya ketrampilan budidaya pertanian potensi produk unggulan; belum adanya ketrampilan pengolahan sampah menjadi pupuk kompos; Sedangkan Sektor Pemerintahan Desa : rendahnya ketrampilan dan penguasaan pemanfaatan TIK; ketata usahaan desa belum baik; lemahnya kemampuan aparat desa dan anggota BPD dalam merancang dan mengendalikan pelakanaan kebijakan desa;

\section{METODE}

Pelaksanaan program pengabdian kepada masyarakat yang diselenggarakan di Desa Pengalangan Kecamatan Menganti Gresik adalah Hibah Pemerintah Provinsi Jawa Timur Tahun 2016" yang terbagi dalam dalam 4 (empat) tahapan kegiatan yaitu : tahap pertama persiapan meliputi kegiatan auediensi tim pelaksana dengan aparatur desa tentang potensi problematika desa kepatihan dan pengalangan; tahap kedua difokuskan pada sektor perekonomian yang bertujuan untuk menumbuh-kembangkan ketrampilan pemberian pelatihan kepada para anggota kelompok tani dan gabungan kelompok tani (Gapoktan) dan ibu-ibu PKK dan karang taruna meliputi kegiatan pelatihan pembuatan pupuk organik (padat dan cair) dan pelatihan budidaya sayur dan tanaman organik (cabei dan bawang merah); tahap ketiga kegiatan difokuskan pada sektor pemerintahan desa dengan tujuan untuk mewujudkan adanya pemerintahan yang efektif dengan program pembangunan desa yang berkualitas serta adminitrasi desa yang efektif dan efisien yang diberikan pembinaan pelatihan ketrampilan pemanfaatan perangkat teknologi informasi dan komunikasi (TIK) dan pelatihan analisis pembuatan kebijakan desa dan program pembangunan desa bagi aparatur desa kepatihan dan pengalangan. Tahap terakhir berfokus pada penyusunan lapoaran kegiatan pengabdian kepada masyarakat dan penyusunan laporan pertanggung jawabaan.

\section{HASIL DAN PEMBAHASAN}

\subsection{Pelaksanaan Program Pengabdian Kepada masyarakat}

Pelaksanaan pengabdian kepada masyarakat di Desa Pengalangan Kecamatan Menganti Kabupaten Gresik terbagi menjadi empat tahapan mengikuti metode yang telah disusun sebagai berikut :

Pada tahap pertama telah diadakan pemetaan potensi dan problematika Desa Kepatihan dan Desa Pengalangan Kecamatan Menganti Kabupaten Gresik sesuai dengan gambar 1. Berdasarkan hasil audiensi yang dilaksanakan Ketua Tim Pelaksana Program pengabdian kepada masyarakat dengan Kepala Desa Penggalangan bertempat di rumah kediaman Kades telah di terpetakan potensi dan problematika yang dihadapi kelompok tani dan aparatur desa penggalangan sebagai berikut : 1). Desa Pengalangan telah ditetapkan oleh Pemerintah Kabupaten Gresik sebagai desa sentra penghasil produk pertanian untuk tanaman cabe merah dan bawang merah dengan mendapatkan program bantuan dari Pemerintah Pusat melalui pembuatan sumur bor program pipa air tetes yang membantu pengairan di musim kemarau; 2). Petani, kelompok tani dan Gapoktan di Desa Pengalangan masih sangat tergantung kepada kebutuhan pupuk buatan dari pabrik sehingga pada waktu jangka panjang berakibat pada keasaman unsur hara tanah. Selain itu kebutuhan pupuk buatan sangat besar sedangkan distribusi pupuk terjadi pembatasan jumlah pupuk bagi petani karena masih bergantung pada subsidi. 3). Perlu tambahan pelatihan dan ketrampilan bagi aparatur desa pengalangan dalam rangka meningkatakan pelayanan kepada masyarakat desa dan pembuatan kebijakan pembangunan desa

$$
\text { Ekonomi, Sosial, dan Budaya }
$$


sejalan dengan dikeluarnya Undang-Undang Nomor 6 Tahun 2014 tentang Pemerintah Desa dan mengakomodir semakin besarnya peran desa dalam pembangunan. Perlu penambahan sarana komputer dan printer untuk memberikan pelayanan kepada masyarakat.

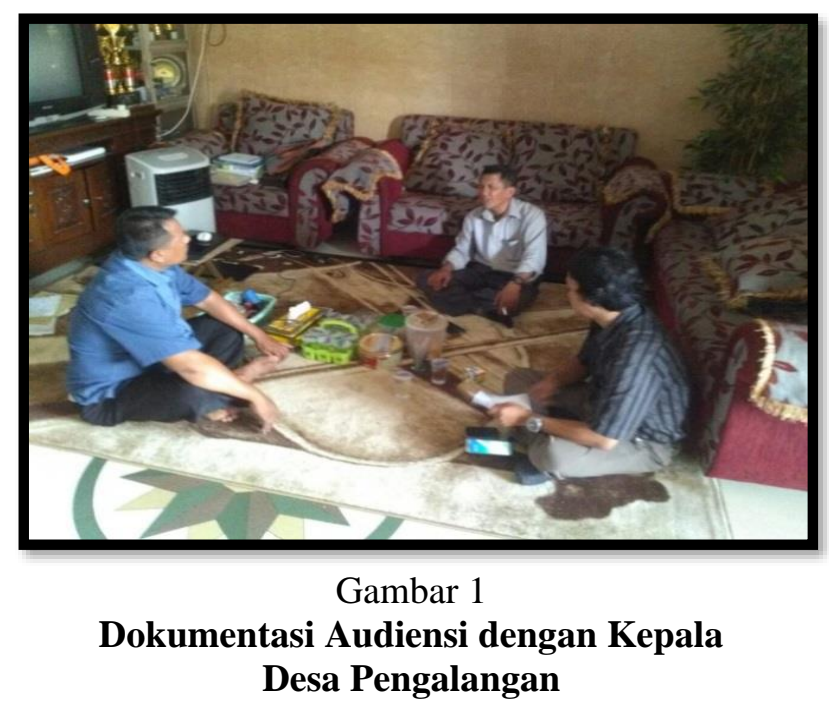

Pada tahap kedua berfokus sektor perekonomiaan desa yang ada di Desa Pengalangan terbagi dalam dua kegiatan pengadaan peralatan pendukung pelatihan dan kegiatan pelatihanpelatihan. Pengadaan dan pembuatan peralatan penunjang pelatihan terdiri beberapa rangkaian kegiatan sebagai berikut : pengadaan mesin cooper, pembuatan komposter, pembuatan rak tanaman, pengadaan peralatan penujang pelatihan, dan penyerahan mesin cooper dapat dilihat pada gambar 2.

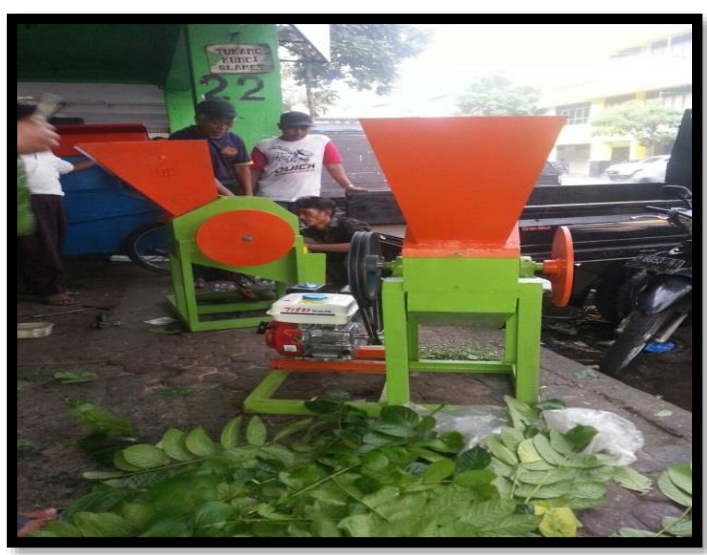

Gambar 2

Mesin Cooper
Sedangkan pelatihan yang dilakukan meliputi : a) Pelatihan pembuatan pupuk padat dari bahan jerami dilaksanakan oleh Tim pelaksana program pengabdian masyarakat dengan melibatkan beberapa kelompok tani untuk masing-masing dusun yang berjumlah 25 (dua puluh lima) orang yang terdiri 1 (satu) orang Ketua Gapoktan Pengalangan, 5 (lima) orang dari dusun bongso wetan, 4 (empat) orang dari dusun bongso kulon, 4 (empat) orang dari dusun sumur geger, 4 (empat) orang dari dusun dukuh, 3 (tiga) orang dari dusun songgat, 4 (empat) orang dari dusun pengalangan. Dalam kegiatan tersebut turut di dampingi Petugas Penyuluh Lapangan (PPL) Bapak Syaiful Apandi, S.P dari Kecamatan Menganti Kabupaten Gresik dan Anggota Babinsa Kecamatan Menganti Gresik (Bapak Sutardik).

b). Pelatihan pembuatan pupuk cair (Lindi) dari bahan daun dan sampah organik yang dilaksanakan oleh Tim pelaksana program pengabdian masyarakat di Balai Desa Pengalangan pada hari Sabtu tanggal 11 Pebruari 2017 dimulai pukul $14.30 \mathrm{~s} / \mathrm{d} \quad 17.00$ WIB dengan dengan melibatkan beberapa kelompok tani untuk masingmasing dusun yang berjumlah 25 (dua puluh lima) orang yang terdiri : 1 (satu) orang Ketua Gapoktan Pengalangan, 5 (lima) orang dari dusun bongso wetan, 4 (empat) orang dari dusun bongso kulon, 4 (empat) orang dari dusun sumur geger, 4 (empat) orang dari dusun dukuh, 3 (tiga) orang dari dusun songgat, 4 (empat) orang dari dusun pengalangan. Pelatihan pembuatan pupuk cair dapa dilihat pada gambar 3
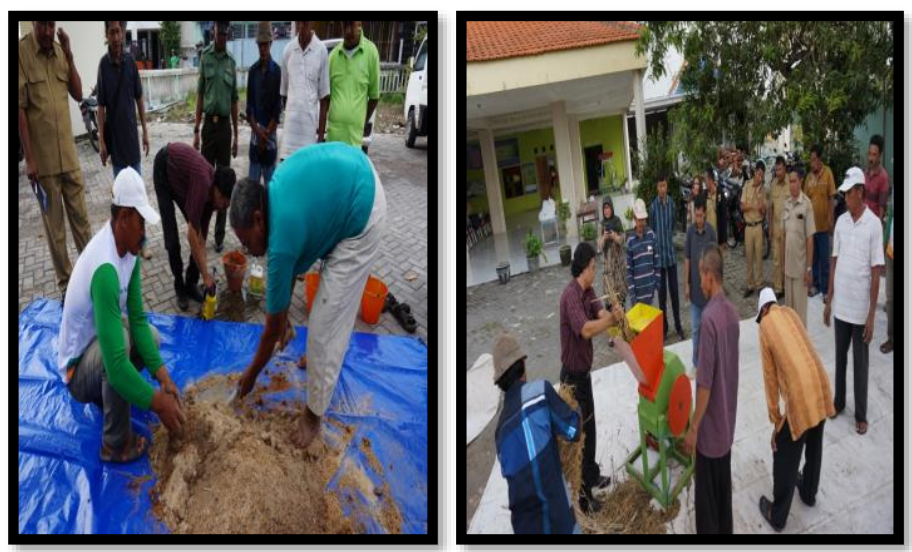

Gambar 3

Pembuatan Pupuk Padat dan Cair 
c). Pelatihan budidaya tanaman organik (sawi, cabai dan bawang merah) yang dilaksanakan di Balai Desa Pengalangan pada hari Sabtu tanggal 25 Pebruari 2017 dimulai pukul 14.30 s/d 17.00 WIB dengan dengan melibatkan beberapa kelompok tani untuk masing-masing dusun yang berjumlah 25 (dua puluh lima) orang yang terdiri : 1 (satu) orang Ketua Gapoktan Pengalangan, 5 (lima) orang dari dusun bongso wetan, 4 (empat) orang dari dusun bongso kulon, 4 (empat) orang dari dusun sumur geger, 4 (empat) orang dari dusun dukuh, 3 (tiga) orang dari dusun songgat, 4 (empat) orang dari dusun pengalangan. Pelatihan budidaya tanaman organik tersebut dapat dilihat pada gambar 5 dibawah ini :
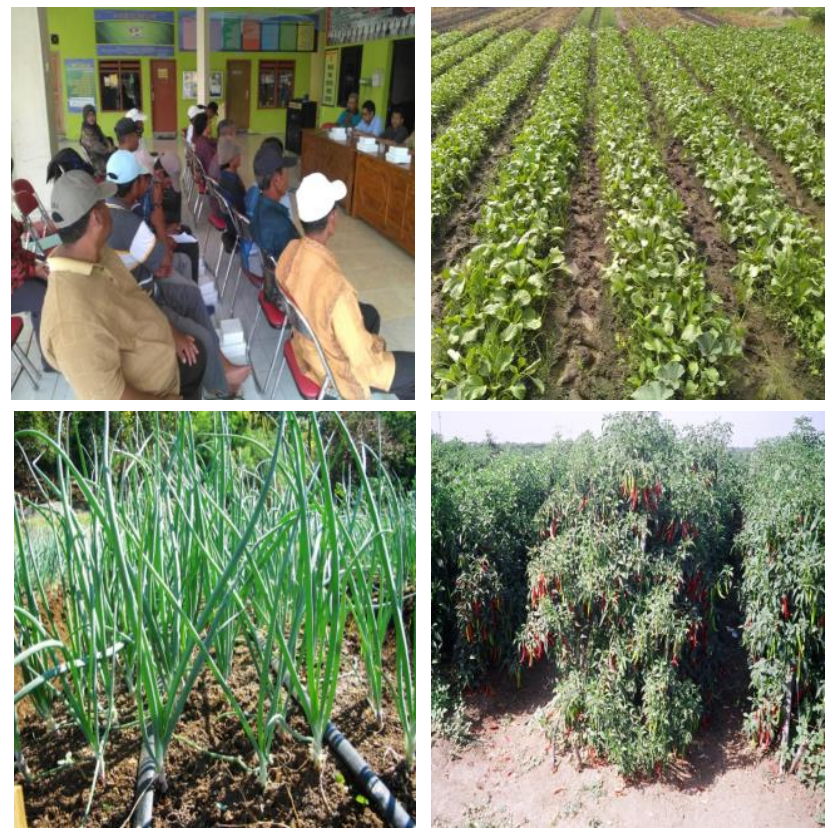

Gambar 5

\section{Pelatihan Budidaya Organik (Sayur, cabai \& Bawang Merah)}

Pendampingan di Desa Pengalangan dilaksanakan pada hari Senin tanggal 20 Pebruari 2017 tentang pengolahan sampah organik untuk gapoktan, selanjutnya dilaksanakan pada hari Kami tanggal 2 Maret 2017 tentang diskusi dengan kades dan poktan tentang permasalahan budidaya dan pemberdayaan petani. Sedangkan pada hari Senin tanggal 20 Maret 2017 tentang diskusi dengan perangkat desa dan kelompok tani tentang program, komoditas unggulan desa (cabai dan bawang merah).
Dalam pelaksanaan kegiatan pada tahap ketiga di fokuskan pada sektor pemerintah desa untuk mewujudkan adanya pemerintahan yang efektif, dengan program pembangunan desa yang berkualitas serta adminstrasi desa yang efisien dan efektif, diberikan pembinaan berupa : a). Pelatihan ketrampilan pemanfaatan perangkat teknologi informasi dan komunikasi (TIK) dilaksanakan oleh Tim pelaksana program pengabdian masyarakat untuk mendukung ketatausahaan dan administrasi pemerintahan desa. Pelatihan ini diperuntukan (terutama) bagi aparatur pemerintah desa. Kegiatan ini dilaksanakan selama dua hari (selasa dan rabu) tanggal 7-8 Maret di Laboratorium komputer Kampus I Universitas Wijaya Putra yang beralamat di Jalan Raya Benowo No. 1-3 yang diikuti oleh 12 (dua belas) orang dari aparatur Desa Pengalangan. Adapun daftar peserta pelatihan operasi program komputer (microsoft office 2010) dapat dilihat pada tabel 1 di bawah ini :

\section{Tabel 1}

\section{Daftar Peserta Pelatihan TIK}

\begin{tabular}{|l|l|l|}
\hline \multicolumn{3}{|l|}{ Desa Pengalangan } \\
\hline No. & \multicolumn{1}{|c|}{ Nama } & \multicolumn{1}{c|}{ Jabatan } \\
\hline 1. & K a s m a d i & Sekretaris Desa \\
\hline 2. & M a t r a i s & Kaur Umum \\
\hline 3. & Aswanto & Kaur Keuangan \\
\hline 4. & Suparman & Kasi Pemerintahan \\
\hline 5. & P a i d i & Kasi Ekobang \\
\hline 6. & S u p a d i & Kasi Kesra \\
\hline 7. & Abdul Kadir & Kasi Trantib \\
\hline 8. & S a m s u r i & Kasun Sumur Geger \\
\hline 9. & J a i n u r i & Kasun Dukuh \\
\hline 10. & Ahmad Sali & Kasun Bongso Wetan \\
\hline 11. & K a s i a d i & Kasun Songat \\
\hline 12. & M u l y o n o & Kasun Bongso Kulon \\
\hline
\end{tabular}

Sumber : Data Primer, 2017 
Pelatihan tersebut dapat dilihat pada gambar 6 dibawah ini :

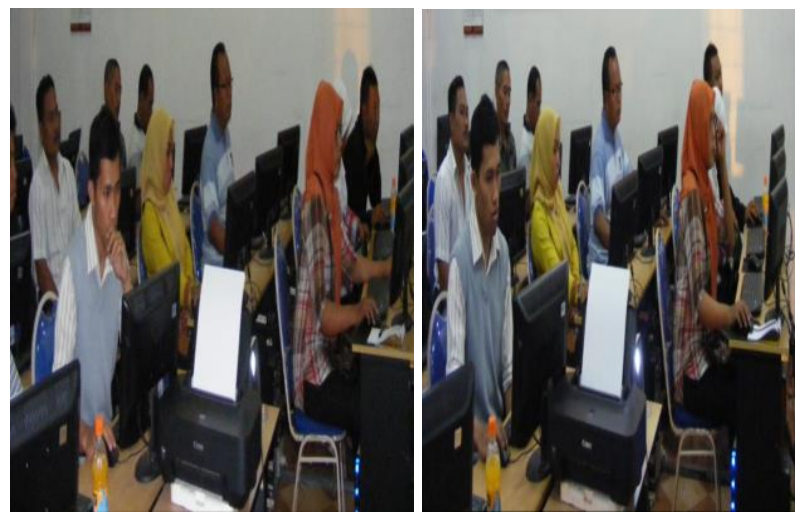

Gambar 6

\section{Pelatihan TIK operasi program Komputer (Microsoft Office)}

Pelatihan analisis pembuatan kebijakan desa dan program pembangunan Desa oleh Tim pelaksana program pengabdian masyarakat. Pelatihan ini diperuntukan bagi aparatur pemerintah desa dan para anggota BPD. Kegiatan ini dilaksanakan selama satu hari Rabu tanggal 15 Maret di Ruang pertemuan Gedung E Lantai 2 Universitas Wijaya Putra yang beralamat di Jalan Raya Benowo No. 1-3 yang 12 (dua belas) orang dari aparatur Desa Pengalangan. Adapun daftar peserta pelatihan Analisis Pembuatan Kebijakan Desa dan Program pembangunan Desa. Pelatihan analisis pembuatan kebijakan desa dapat dilihat pada gambar 7 dibawah ini :
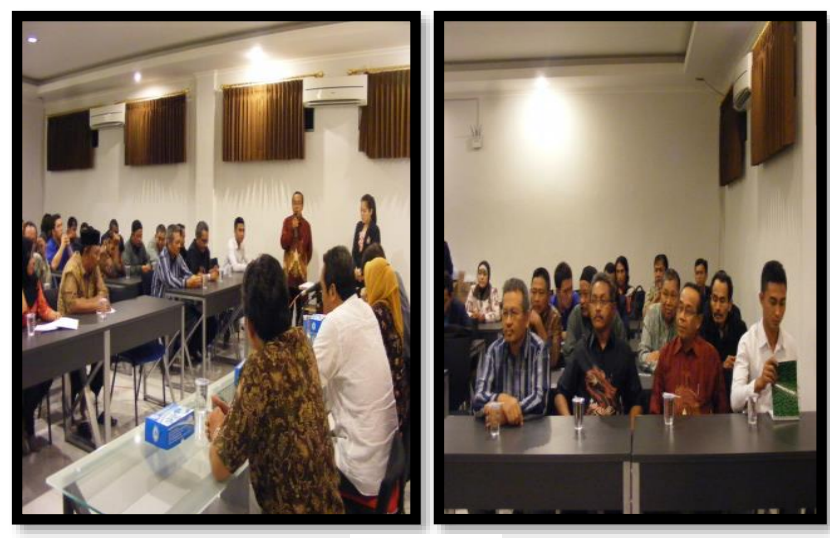

Gambar 7

Pelatihan Analisis Pembuatan Kebijakan \& Pembangunan Desa
Kegiatan selanjutnya penyerahan bantuan peralatan pendukung untuk mendukung operasional dan pelayanan kepada masyarakat desa tim pelaksana program pengabdian masyarakat memberikan bantuan satu unit komputer PC dan satu unit printer Epson L120 untuk desa. Penyerahan bantuan di Desa Pengalangan diberikan pada hari Jum'at, 17 Maret 2017 yang diserah terimakan kepada Kepala Desa Pengalangan di Kantor Balai Desa Pengalangan. Kegiatan tersebut dapat dilihat pada gambar 8 di bawah ini :
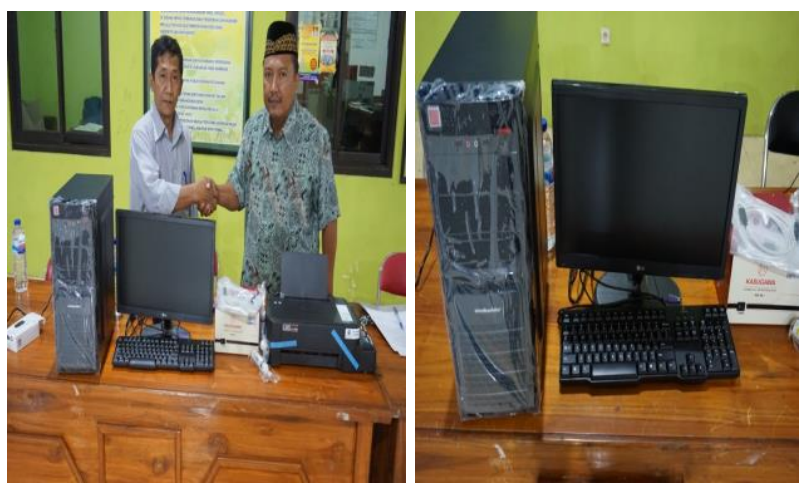

Gambar 8

Penyerahan Bantuan Komputer dan Printer

Pada tahap empat difokuskan pada penyusunan laporan kegiatan dan laporan pertanggung jawab yang dimulai rapat anggota tim pelaksana program pengabdian masyarakat Hibah Pemerintah Provinsi Jawa Timur tahun 2016 yang dilaksanakan tanggal 22 Maret 2017 penyusunan laporan kegiatan dan penyusunan laporan pertangung jawaban kegiatan pengabdian masyarakat di Desa Pengalangan Kecamatan Menganti Kabupaten Gresik.

Dalam melaksanakan kegiatan pengabdian kepada masyarakat tim pelaksana program pengabdian masyarakat menggunakan dana hibah untuk membiayai pelaksanaan pelatihan-pelatihan dan praktek tanam budidaya tanaman organik dan untuk membiaya operasional kegiatann pengabdian masyarakat.

Berikut ini kami lampirkan daftar pendanaan untuk pembelian peralatan praktek dan bantuan untuk peningkatan pelayanan kepada

$$
\text { Ekonomi, Sosial, dan Budaya }
$$


masyarakat di Desa Pengalangan dapat dilihat pada tabel 2 dibawah ini :

\section{Tabel 2}

Pendanaan dan Pemanfaatan Dana Kegiatan Program Pengabdian Kepada Masyarakat

\begin{tabular}{|c|c|c|}
\hline $\mathbf{N}$ & $\begin{array}{c}\text { Pendanaan } \\
\text { Kegiatan } \\
\end{array}$ & Pemanfaatan \\
\hline 1. & 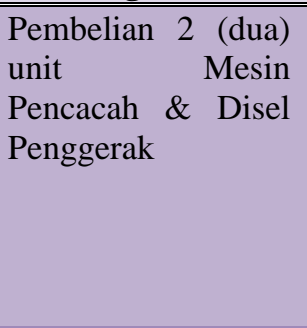 & $\begin{array}{llr}\checkmark & \begin{array}{l}\text { Satu unit untuk } \\
\text { bantuan bagi }\end{array} \\
\text { Gabungan Kelompok } \\
\text { Tani (Gapoktan) Desa } \\
\text { Pengalangan } \\
\checkmark & \begin{array}{l}\text { Praktek pelatihan } \\
\text { pembutan pupuk padat } \\
\text { dan cair }\end{array}\end{array}$ \\
\hline 2. & $\begin{array}{l}\text { Pembelian bibit } \\
\text { tanaman (sawi, } \\
\text { cabe dan terong) } \\
\text { dan } 200 \text { (dua ratus) } \\
\text { buah siap tanam }\end{array}$ & $\begin{array}{l}\text { Untuk praktek pelatihan } \\
\text { budidaya sayur organik }\end{array}$ \\
\hline 3. & $\begin{array}{l}\text { mbuatan } 2 \text { (buah) } \\
\text { mposter }\end{array}$ & $\begin{array}{l}\text { Untuk praktek pelatihan } \\
\text { pembuatan pupuk cair } \\
\text { untuk Desa Pengalangan }\end{array}$ \\
\hline 4. & $\begin{array}{l}\text { mbuatan } \\
\text { mpat) Rak tanam }\end{array}$ & 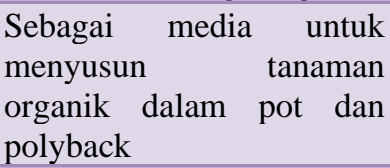 \\
\hline 5. & 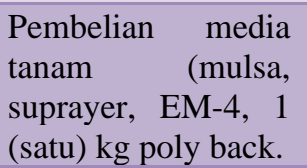 & $\begin{array}{l}\text { Untuk praktek pelatihan } \\
\text { budidaya sayur organik } \\
\text { untuk desa kepatihan dan } \\
\text { pengalangan }\end{array}$ \\
\hline 6. & $\begin{array}{l}\text { Pelatihan } \\
\text { Pembuatan Pupuk } \\
\text { Organik (Padat) }\end{array}$ & $\begin{array}{l}\text { Mengurangi sampah } \\
\text { organik dan mengurangi } \\
\text { biaya pupuk buatan }\end{array}$ \\
\hline 7. & $\begin{array}{l}\text { Pelatihan } \\
\text { Pembuatan Pupuk } \\
\text { Cair }\end{array}$ & $\begin{array}{l}\text { Mengurangi } \\
\text { organik dan mengurangi } \\
\text { biaya pupuk buatan \& } \\
\text { pemanfaatan limbah urine } \\
\text { sapi }\end{array}$ \\
\hline 8. & $\begin{array}{l}\text { Pelatihan Budidaya } \\
\text { Tanaman Organik } \\
\text { (cabe, sawi dan } \\
\text { Bawang merah }\end{array}$ & $\begin{array}{l}\text { Meningkatan produktivitas } \\
\text { dan kesejateraan para } \\
\text { kelompok tani, PKK dan } \\
\text { Karang Taruna di desa } \\
\text { Pengalangan }\end{array}$ \\
\hline 9. & $\begin{array}{l}\text { Pelatihan TIK bagi } \\
\text { aparatur desa dan } \\
\text { BPD } \\
\text { Pengalangan }\end{array}$ & $\begin{array}{l}\text { Meningkatkan ketrampilan } \\
\text { aparatur desa untuk } \\
\text { memberikan pelayan yang } \\
\text { berkualitas } \\
\text { masyarakat }\end{array}$ \\
\hline 10 & $\begin{array}{lr}\text { Pelatihan } & \text { Analisis } \\
\text { Kebijakan } & \text { dan }\end{array}$ & $\begin{array}{l}\text { Meningkatkan ketrampilan } \\
\text { aparatur desa dalam }\end{array}$ \\
\hline
\end{tabular}

\begin{tabular}{|l|l|l|}
\hline & Pembangunan Desa & $\begin{array}{l}\text { menyusun program } \\
\text { pembangunan desa yang } \\
\text { berdasarkan pada potensi } \\
\text { wilayah. }\end{array}$ \\
\hline 11 & $\begin{array}{l}\text { Pembelian 2 (dua) } \\
\text { unit PC komputer }\end{array}$ & $\begin{array}{l}\text { Mendukung aparatur desa } \\
\text { kepatihan dan pengalangan } \\
\text { dalam rangka } \\
\text { meningkatkan pelayanan } \\
\text { bagi masyarakat desa } \\
\text { tersebut. }\end{array}$ \\
\hline 12 & $\begin{array}{l}\text { Pembelian 2 (dua) } \\
\text { unit Printer merk } \\
\text { Epson L120 }\end{array}$ & $\begin{array}{l}\text { Mendukung aparatur desa } \\
\text { kepatihan dan pengalangan } \\
\text { dalam rangka } \\
\text { meningkatkan pelayanan } \\
\text { bagi masyarakat desa } \\
\text { tersebut. }\end{array}$ \\
\hline 13 & $\begin{array}{l}\text { Pembelian 2 (dua) } \\
\text { unit PC komputer } \\
\text { kendukung aparatur desa } \\
\text { kepatihan dan pengalangan } \\
\text { dalam rangka } \\
\text { meningkatkan pelayanan } \\
\text { bagi masyarakat desa } \\
\text { tersebut. }\end{array}$ \\
\hline
\end{tabular}

\subsection{Hasil Kegiatan Program Pengabdian Kepada Masyarakat}

Pelaksanaan program pemberdayaan desa ini bertujuan untuk mendukung upaya pemberdayaan ekonomi masyarakat dan pendayagunaan pemerintahan desa yang efektif. hasil yang hendak telah dicapai :

a. Sektor Perekonomian Desa

1) Terbentuknya kelompok Tani Wanita, yang dapat secara nyata berkiprah untuk : (a) menggerakan dan mendayagunakan anggotanya untuk berkarya nyata dalam membangun desa; (b) secara kolektif mengelola potensi ekonomi pertanian desa secara efisien dan efektif serta berkelanjutan.

2) Tumbuh-kembangnya ketrampilan masyarakat, khususnya anggota kelompok tani wanita desa, dalam mengelola budidaya pertanian yang diproyeksikan menjadi proguk unggulan.

$$
\text { Ekonomi, Sosial, dan Budaya }
$$


3) Tumbuh-kembangnya ketrampilan mengolah pupuk organik (kompos) yang berbahan dasar sampah organik, dan kepemilikan peralatan pengolahan pupuk kompos.

4) Terwujudnya produk unggulan desa yang berbasis pada produk pertanian, yaitu: (a) buah organik dan (b) sayur organik.

b. Sektor Pemerintahan Desa

1) Tumbuhnya kemampuan dan ketampilan aparatur desa dan anggota BPD dalam pemanfaatan teknologi informasi dan komunikasi (TIK)

2) Semakin tertib dan tertatanya pengelolaan ketata usahaan desa, dengan berbasis pemanfaatan TIK

3) Tumbuhnya kemampuan aparatur desa dan anggota BPD dalam menyusun kebijakan desa dan program pembangunan desa yang berbasis pada analisis perumusan kebijakan yang rasional.

\section{KESIMPULAN}

Berdasarkan pelaksanaan program pemberdayaan masyarakat yang telah dilaksanakan di Desa Pengalangan telah memberikan dampak positif bagi perekonomian desa dan pemerintah desa.

Pada sektor ekonomi mampu meningkatkan perekonomian desa dengan terbentuknya kempok tani wanita dengan menghasilkan produk unggulan desa bidang pertanian berupa sayur organik, cabe dan bawang merah. Produk unggulan desa pengalangan mampu mensuplai kebutuhan sayur organik di Pasar modern (Pasar Ciputra). Pada tahun selanjutnya telah dirintis pembangunan pasar desa sebagai tempat sentra produk unggulan Desa.
Sedangkan pada sektor Pemerintah Desa hasil yang dicapai adalah pertama tumbuhnya kemampuan dan ketampilan aparatur desa dan anggota Badan Permusyawaratan Desa (BPD) dalam pemanfaatan teknologi informasi dan komunikasi (TIK); kedua semakin tertib dan tertatanya pengelolaan ketata usahaan desa, dengan berbasis pemanfaatan TIK; ketiga Tumbuhnya kemampuan aparatur desa dan anggota BPD dalam menyusun kebijakan desa dan program pembangunan desa yang berbasis pada analisis perumusan kebijakan yang rasional sehingga program desa semakin produktif, akuntabel dan transparan dalam pengelolaan dana desa.

\section{UCAPAN TERIMAKASIH}

Ucapan terimakasih disampaikan kepada lembaga/institusi yang telah memberikan kontribusi dalam pelaksanaan kegiatan.

1. Ucapan terima kasih disampaikan kepada Peme rintah Provinsi Jawa Timur karena telah memberikan pendanaan program pengabdian kepada masyarakat melalui DIPA Anggaran tahun 2016

2. Ucapan terima kasih diberikan kepada Fakultas Ilmu Sosial dan Ilmu Politik Universitas Wijaya Putra karena telah memberikan kesempatan dan dukungan sarana untuk menggunakan Laboraorium Komputer untuk melaksanakan pelatihan TIK.

\section{REFERENSI}

Undang-Undang Nomor 6 Tahun 2014 tentang Pemerintah Desa;

Peraturan Menteri Pendayagunaan Aparatur. Negara dan Reformasi Birokrasi Nomor 20 Tahun. 2010 tentang Road Map Reformasi Birokrasi 2010; 